\title{
The theory and practice of steam engineering in Britain and France, 1800-1850
}

La théorie et la pratique des techniques de la vapeur

en Grande-Bretagne et en France, 1800-1850

\section{Alessandro Nuvolari}

\section{OpenEdition \\ Journals}

Édition électronique

URL : http://journals.openedition.org/dht/1439

DOI : $10.4000 /$ dht. 1439

ISSN : 1775-4194

Éditeur :

Centre d'histoire des techniques et de l'environnement du Cnam (CDHTE-Cnam), Société des élèves du CDHTE-Cnam

\section{Édition imprimée}

Date de publication : 1 décembre 2010

Pagination : 189-197

ISBN : 978-2-9530779-5-7

ISSN : 0417-8726

\section{Référence électronique}

Alessandro Nuvolari, «The theory and practice of steam engineering in Britain and France

1800-1850", Documents pour I'histoire des techniques [En ligne], 19| $2^{\mathrm{e}}$ semestre 2010, mis en ligne le 21 juin 2011, consulté le 08 septembre 2020. URL : http://journals.openedition.org/dht/1439 ; DOI : https://doi.org/10.4000/dht.1439 


\title{
The theory and practice of steam engineering in Britain and France, 1800-1850
}

\author{
Alessandro Nuvolari \\ LEM (Laboratory of Economics and Management) \\ St. Anna School of Advanced Studies, Pisa
}

\begin{abstract}
C
omparative assessments of the use of steam power technology in Britain and in France during the first of the half of the nineteenth century have a curious, almost paradoxical history. On the one hand, economic historians, in contributions devoted to the study of the origins and diffusion of industrialization from England to continental Europe, have typically described France as a technological laggard in many areas, including the use of steam power. This assessment is mainly based on comparative estimates of the number of steam HP installed in the two countries such as those reported here in figure $1 .{ }^{1}$ On the other hand, historians of technology have pointed out the prolonged resilience of the Boulton and Watt low-pressure engine design in England, despite the fact that throughout the 1810s and 1820s, a number of engineers such as Trevithick and Woolf had successfully developed more fuel efficient high pressure expansive designs that were more fuel efficient. In Britain, these high pressure expansive designs did not become popular for industrial applications until at least the late 1840s. Several contemporary engineers considered this situation as an expression of irrational technological conservatism. Interestingly enough, the same designs were instead quickly adopted in France, so that in 1820s the Woolf compound design had become the standard design for steam engines used in French factories and workshops. ${ }^{2}$

The aim of this chapter is to provide a re-assessment of the factors accounting for delayed adoption of the high pressure expansive design in England and for its precocious diffusion in France.
\end{abstract}

1 See for example the discussion in David S. Landes, The Unbound Prometheus, Cambridge, Cambridge University Press, 1969, pp. 220-221

2 See Jacques Payen, "La technologie des machines a vapeur in France de 1800 a 1850" in L'Acquisition des Techniques par le Pays Non-Initiateurs, Paris, 1973, pp. 388-389.

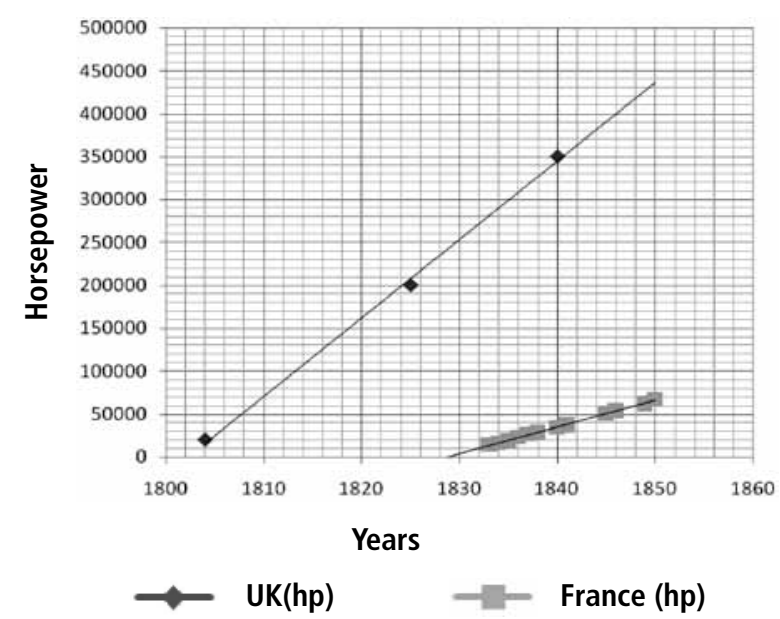

fig. 1 - Steam Engine Diffusion in Britain and in France, 1800-1850 Source : Anne van Neck, Les débuts de la machine à vapeur dans l'industrie belge, 1800-1850, Bruxelles, Palais des Académies, 1979, p. 770.

\section{The development and diffusion of the high pressure expansive engine in England and in France}

The first technically successful use of high-pressure steam can be ascribed to the "puffer" engines designed by Richard Trevithick around 1800. In these engines, high-pressure steam, after the stroke, was discharged into the atmosphere, rather than being conveyed into the separate condenser. The chief advantage of these engines was their compactness and cheaper cost of installation (due to the elimination of the condenser, the air pump and the beam). However, this high-pressure non-condensing engine did not make use of early cut-off and was less efficient than Watt low-pressure engines, as it tended to consume about $25 \%$ more coal. ${ }^{3}$ In Britain,

3 Nick Von Tunzelmann, Steam power and British industrialization 


\section{The theory and practice of steam engineering in Britain and France, 1800-1850}

the compactness of this engine design would make it the most natural option for railway use, but it did not find widespread use in industrial applications where the Watt low-pressure engine remained dominant.

The use of high-pressure steam for attaining fuel economies was the outcome of the parallel efforts of the Cornish engineers Richard Trevithick and Arthur Woolf. In the early 1810s they developed engines in which high-pressure steam was employed expansively. These engines also made use of the separate condenser which permitted the exploitation of a larger range of operating temperatures (although the rationale for this design feature was not fully understood until the 1850s with the formulation of classical thermodynamics). The layout of the high-pressure condensing engine developed by Trevithick, making use of beam, separate condenser and air pump, was substantially the same as a Watt lowpressure engine, with the key exception of a new form of tubular boiler for the generation of high-pressure steam. ${ }^{4}$ Woolf instead adopted a so-called compound design in which steam was expanded subsequently in two cylinders.

It is not surprising that these pioneering developments of the high-pressure expansive engine took place in the Cornish mining district. By comparison with other locations, one of the distinctive features of the Cornish mining economy was the high price of coal. As a result, Cornish mining entrepreneurs were keenly interested in improvements in the fuel efficiency of the steam engines that could curtail their costly fuel bills. From 1811, they sponsored a monthly publication containing detailed reports on the performance (measured in millions of lbs. of water lifted one foot high per consumption of a bushel of coal, or, as it was termed by contemporary engineers, the "duty" of the engine), technical details and operating procedures of the steam engines at work in the county. The explicit intention was twofold. First, the publication would permit the rapid identification and diffusion of bestpractice techniques. Second, it would create a climate of competition in the Cornish engineering community with favorable effects on the rate of technical progress. Joel Lean, a highly respected mine "captain" was entrusted with the compilation of the reports and the publication was generally known as Lean's engine reporter. ${ }^{5}$

to 1860, Oxford, Clarendon Press, 1978, p. 22.

4 Later on, this type of boiler would be termed "Cornish" in the contemporary engineering literature.

5 The first three reports were published in West Briton, a local newspaper. From 1812, Lean's Engine Reporter appeared as an independent publication. Joel Lean died in September 1812. After his death, the reporter was first continued by his sons Thomas (I) and John, and other members of the Lean family later on. The final years (1897-1904) were covered by J. C. Keast.
In a previous article, I have argued that the Cornish mining district in the first half of the nineteenth century can be seen as an example of what Robert Allen has termed "collective invention settings". Within "collective invention settings", rival firms or independent individual inventors freely release to one another pertinent information concerning the solution of technical problems, rather than appropriating it by means of patents or secrecy. Each firm, in turn, makes use of the received information to incrementally improve on a basic common technological design. In Cornwall, the chief channel through which information concerning the technological characteristics and the performance of the engines was released was clearly Lean's engine reporter. ${ }^{6}$

In retrospect, it is not surprising that competent contemporary observers paid great attention to technological developments in Cornwall as portrayed in the engine reports. A large body of the contemporary engineering literature on steam technology was precisely informed by the debate on the different choice of technique characterizing the use of steam power in Cornwall (where the high-pressure expansive engine was adopted) versus the rest of Britain, especially the manufacturing districts of the North, where the favourite option remained the Watt low-pressure engine.

The superior fuel efficiency of the Cornish practice led some contemporary observers to describe this situation as a case of "entrepreneurial failure", with the rest of country unduly hesitant in their transition to the high-pressure expansive engine. For example, William Fairbairn, an authoritative member of the Lancashire engineering community, and one of the leading advocates of the merits of the high-pressure expansive engine whose pleadings remained for a long period unfulfilled, wrote in 1849:

"For a great number of years a strong prejudice existed against the use of high-pressure steam and it required more than ordinary care in effecting the changes which have been introduced: it had to be done cautiously, almost insidiously, before it could be introduced. The author of this paper believes he was amongst the first in the Manufacturing Districts who pointed out the advantages of high-pressure

See Bridget Howard, Mr. Lean and the engine reporters, Penryn, Trevithick Society, 2002 for biographical details of the various compilers of the reports.

6 Robert C. Allen, "Collective invention", Journal of economic behavior and organization, 4, 1983, pp. 1-24. For a discussion of the operation of collective invention in Cornish mining district, see Alessandro Nuvolari, "Collective invention during the British industrial revolution: the case of the Cornish pumping engine", Cambridge Journal of Economics, 28, 2004, pp. 347-363. 
steam when worked expansively, and for many years he had to contend with the fears and prejudices of the manufacturers". ${ }^{7}$

Similarly, John Farey vigorously denounced a widespread and culpable "state of apathy as to consumption of fuel" in the "great manufacturing districts of the North". 8

According to James Nasmyth, the inventor of the steam hammer, the actual beginnings of the adoption of high pressure with expansion in Lancashire could be reasonably dated to in the late 1840s when "timid and prejudiced traditions" had been finally dissipated. In a letter of 1852 cited by factory inspector Leonard Horner, Nasmyth wrote:

"The engine power of this district [Lancashire] lay under the incubus of timid and prejudiced traditions for nearly forty years, but now we are happily emancipated. During the last fifteen years, but more especially in the course of the last four years [since 1848] some very important changes have taken place in the system of working condensing steam engines ... The result has been to realize a much greater amount of duty or work performed by identical engines, and that again at a very considerable reduction of the expenditure of fuel ..."

These passages suggest that, despite numerous solicitations, many engineers and practitioners had remained extremely skeptical, at least till the late 1830s, about the fuel advantages of using high-pressure steam expansively. Since the superior fuel efficiency of the highpressure expansive engine had remained theoretically mysterious, the dramatic early rise of the duty of the (bestpractice) Cornish expansive engines (in the 1810s up to more than 40 millions and by the late 1820 s to more than 80 millions) was not easily accepted outside Cornwall. In fact, several doubts were voiced on the actual levels of efficiency achieved by Cornish engines, actually denying the existence of a Cornish technological lead. In 1838, G. H. Palmer published an article in the authoritative Transactions of the Institution of Civil Engineers, in which he contended that the levels of fuel efficiency claimed for the Cornish engine were undoubtedly exaggerated (because in open contrast with the caloric theory of heat): ${ }^{10}$

7 William Fairbairn, "On the Expansive Action of Steam, and a New Construction of Expansion Valves for Condensing Steam Engines" , Proceedings of the Institution of mechanical engineers, 1, 1847-1849, pp. 23-24.

8 John Farey, A treatise on the steam engine, Historical, practical and descriptive. Volume II, Newton Abbot, David \& Charles, 1971, p. 307.

9 P.P. 1852, XL, p. 484.

10 In the same article, G. H. Palmer, on the basis of the caloric
"If the statements given to the public by the Cornish engineers, whose sincerity I cannot doubt are correct, I dare not trust to call nature to account for the undue favouritism she confers upon our Cornish friends by enabling them to perform results that the London, Manchester and Birmingham engineers cannot approach ... Upon what principle then, permit me to ask, can the Cornish engines perform so much more than all other engines. Strong, indeed, should be the evidence that ought to outweigh or cancel the... laws of nature, and induce this Institution to sanction statements of duty more than double of the best Watt engine, and still more, surpassing the limits Nature has assigned steam to perform". ${ }^{11}$

The most strenuous defender of Lancashire technical practice was perhaps Robert Armstrong. In his Essay on the boilers of steam engines published in 1839, he declared that the Cornish duty figures were undoubtedly "gross exaggerations", the real duty probably being equal to about 30 millions. He concluded that "there is nothing in their [Cornish] system of management that can be profitably imitated here [Lancashire]". ${ }^{12}$

If we turn to the French case, it is possible to characterize the history of steam engineering from 1700-1850 as divided in three stages: i) a first phase of autonomous experimentation, ii) a phase of technological dependence and imitation (going from the years of Watt's invention of the separate condenser to the Restoration), iii) a phase of creative adaptation of British inventions and successful catching up (marked by the widespread adoption of Woolf compound design). Historians of technology have properly given credit to Thomas Newcomen for pioneering the development of steam power technology, by designing the first fully operational steam engine. ${ }^{13}$ To be sure, Newcomen's contribution to steam technology was a major one and of probably unparalleled historical significance. However, it is important to recognize, that Britain was not the only country involved in early experimentation with steam engine designs. For example, Cugnot in the 1760s proposed an interesting design of a high-pressure steam tractor to be used for pulling cannons. According to Allen, the key-difference between

theory of heat, fixed the maximum duty attainable by a steam engine to 44 millions. Palmer, G. H, 'On the application of steam as a moving power, considered especially with reference to the economy of atmospheric and high pressure steam', Transactions of the Institution of civil engineers, 2, 1838, pp. 33-46

11 Ibid., pp. 44-46.

12 Robert Armstrong, An essay on the boilers of steam engines, London, 1839, p. 76.

13 See, in particular, Donald Cardwell, The Fontana history of technology, London, Harper, 1994. 


\section{The theory and practice of steam engineering in Britain and France, 1800-1850}

these early experimentations in England and France was not so much one of different inventive or engineering abilities, but one of different economic environments. Steam engine design and construction did represent a substantial investment and, given the low levels of fuel efficiency of early steam engine designs, this investment was likely to turn out to be profitable only in locations with low coal prices. Thus, the abundance of coal in Britain and its scarcity in France are the key-determinants of the different commitment of the two countries to the development of steam power technology during the eighteenth century. ${ }^{14}$ In this perspective, it is not surprising that the key breakthroughs in steam technology of the eighteenth century (Newcomen's atmospheric engine and Watt's separate condenser) occurred in Britain. As Allen aptly points out, both inventions did require substantial economic outlays for being put into practice. Interestingly enough, the minimal role of steam power technology in the French economy, did not prevent French scientists and engineers from becoming keenly interested both at theoretical and practical level in steam engineering. As pointed by Robert Fox, one of the main factors accounting for the interest of French scientists in the British achievements in steam engineers were their implications for the experimental and theoretical study of the thermal properties of matter in a gaseous state, a prominent area of research for many French scientists. ${ }^{15}$ The Revolutionary and Napoleonic wars resulted in a forced interruption of most of the information channels used by French scientists and engineers to keep abreast with the evolution of steam engineering in Britain. Thus, especially after 1815, the news of the successful design of high pressure expansive engines by Trevithick and Woolf in Cornwall and of their staggering improvements in fuelefficiency was received with enthusiasm, which was not tempered, as in Britain, by skepticism and attachment to James Watt's designs and reputation. ${ }^{16}$ In the early 1810 s

14 Robert C. Allen, The British industrial revolution in a global perspective, Cambridge, Cambridge university press, 2009.

15 Robert Fox, "The challenge of a new technology. Theorists and the high pressure steam engine before 1824", in Sadi Carnot et l'essor de la thermodynamique, Paris, École polytechnique, 1974, pp. 149-167.

16 R. Fox, op. cit., p. 151. In the 1810 s the Cornish engine reports were reprinted regularly in Annales de chimie et de physique. See Donald Cardwell, From Watt to Clausius, London, Heinemann, 1971, p. 157, also for other examples of early French inquiries on the performance of Cornish steam engines. The role played by James Watt's authority (which had sanctioned the low pressure engine as the optimum) for accounting for the hesitancy in developing the high pressure expansive design for industrial applications is discussed by Richard Hills, "The development of the steam engine from Watt to Stephenson", History of
Humphrey Edwards broke his partnership with Woolf and moved to France where, under the protection of a brevet d'importation, he introduced the rotative compound design. As mentioned, this type of design became immediately very popular. According to a contemporary estimate, by 1824, already some 300 of this type engines had been installed. ${ }^{17}$ After the expiration of Edwards' patent several other firms took over the construction of the Woolf engine and the rotative compound design became the standard option in French manufacturing application of steam power. As a result of these developments, from the 1820s, the practice of steam engineering in Britain and France diverged. We do not see anymore French engineers importing and imitating British low pressure designs, as during the eighteenth and early nineteenth century. Instead, we see the successful adaptation of a design that was not popular in Britain to French local conditions. ${ }^{18}$

\section{Factor prices and choice of technique}

A possible explanation of these two diverging paths in steam engineering practice is that they reflected the factor prices prevailing in each location (in particular the price of coal). We should notice here that the high pressure expansive engine has higher capital outlays per HP. If this interpretation is correct, by the 1820s, in the two countries, there was not anymore a situation of leader vs. follower, but simply a different choice of technique dictated by different economic environments.

It is possible to examine in some detail two cases of adoption of the high-pressure engines in the late 1830s and early 1840s in England and carry out some simple profitability assessments. ${ }^{19}$ In the case of the purchase of a new engine, an entrepreneur will be indifferent between a high-pressure and low-pressure engine when (1) $\boldsymbol{K}_{H}(\boldsymbol{i}+\boldsymbol{d})+\boldsymbol{C}_{H} \cdot \boldsymbol{H} \cdot \boldsymbol{p}_{C}=\boldsymbol{K}_{L}(\boldsymbol{i}+\boldsymbol{d})+\boldsymbol{C}_{L} \cdot \boldsymbol{H} \cdot \boldsymbol{p}_{C}$

technology, 25, 2004, pp. 180-197.

17 R. Jenkins, "A Cornish engineer: Arthur Woolf, 1766-1837", Transactions of the Newcomen Society, 13, 1932-33, p. 61.

18 N. Von Tunzelmann, op. cit. (3), p. 281 cites this particularly enlightening passage from the answers given by the engineer Grenville Withers to the Select Parliamentary Committee on the Exportation of Machinery in 1841: "English steam engines are getting into very great disrepute, in general because the consume so much coal ... in France and Belgium, manufacturers find that Wolf's [sic] principle of steam engine, which is both high and low pressure, is on a much more economical system, that is, it burns less coal".

19 These profitability assessments are discussed in detail in Alessandro Nuvolari and Bart Verspagen, "Technical choice, innovation and British steam engineering, 1800-1850", Economic history review, vol. 62(3), 2009, pages 685-710. 
In the formula, $\boldsymbol{K}_{H}$ represents the capital costs per HP for the high-pressure engine, $\boldsymbol{i}$ is the annual interest rate, $\boldsymbol{d}$ is the depreciation rate, $\boldsymbol{C}_{H}$ is the consumption of coal per HP-hour for the high-pressure engine, $\boldsymbol{H}$ is the amount of working hours in the year, $\boldsymbol{p}_{c}$ is the price of coal, $\boldsymbol{K}_{L}$ is the capital cost per HP for the low-pressure engine and $\boldsymbol{C}_{L}$ is the coal consumption per HP-hour of the low-pressure engines. The formula can be used to calculate the "threshold" coal price for the technical choice between the two types of engines, $\boldsymbol{p}_{c}$.

\section{(2) $\boldsymbol{p}_{\mathrm{c}}=\frac{\left(\boldsymbol{K}_{H}-\boldsymbol{K}_{L}\right)(\boldsymbol{i}+\boldsymbol{d})}{\left(\boldsymbol{C}_{L}-\boldsymbol{C}_{H}\right) \boldsymbol{H}}$}

In other words, if the price of coal is equal to $\boldsymbol{p}_{c}$ an entrepreneur will be indifferent between a high-pressure and low-pressure engine. If the price of coal is higher than $\boldsymbol{p}_{c}$ it will be economic to adopt the high-pressure engine, vice versa if the price is lower, the low-pressure engine represents the optimal choice.

In case there is an already installed low-pressure engine, an entrepreneur will be indifferent between installing a new high-pressure one and keeping the old one when

(3) $\boldsymbol{K}_{H}(\boldsymbol{i}+\boldsymbol{d})+\boldsymbol{C}_{H} \cdot \boldsymbol{H} \cdot \boldsymbol{p}_{\mathrm{C}}=\boldsymbol{C}_{L} \cdot \boldsymbol{H} \cdot \boldsymbol{p}_{\mathrm{C}}$

In this case the threshold coal price is given by

$$
\text { (4) } \boldsymbol{p}_{c}=\frac{\boldsymbol{K}_{H}(\boldsymbol{i}+\boldsymbol{d})}{\left(\boldsymbol{C}_{L}-\boldsymbol{C}_{H}\right) \boldsymbol{H}}
$$

We will examine first the profitability of adopting a highpressure expansive engine for pumping applications (the user context most similar to the Cornish case). One of the first high-pressure expansive pumping engines installed outside Cornwall was erected at the East London Waterworks as late as 1838. The installation was preceded by a travel of Thomas Wicksteed to Cornwall where he conducted a detailed research on the merits of the Cornish engine. ${ }^{20}$ Although Wicksteed heartily encouraged the adoption of Cornish engines, the management of the waterworks remained reluctant. Finally, in 1838 a secondhand Cornish engine was purchased for $£ 7600$ under the condition that it would perform a duty of 90 millions over twelve consecutive months, otherwise a penalty had to be paid. Once the engine was installed, Wicksteed made a systematic comparison of the performance of the new Cornish engine with that of a Boulton and Watt engine. ${ }^{21}$ In table 1 , we assess the profitability of

20 Thomas Wicksteed, An experimental inquiry concerning Cornish and Boulton \& Watt engines, London, 1841. $21 \mathrm{lbid}$. adopting high-pressure expansive engines for pumping applications in the late 1830s using Wicksteed's data. As it is hard to estimate a typical number of working hours for engines employed in water-works, we have computed the threshold coal price for a reasonable range of possible values. ${ }^{22}$ The upshot of the results of table 1 is rather striking (although probably not fully surprising for a reader acquainted with the contemporary engineering discussions). At the high price of coal (around $20 \mathrm{~s}$.) prevailing in London, it would have been worthwhile to scrap all the installed low-pressure engines replacing them with new high-pressure engines.

Some teething technical problems hampered the adoption of high-pressure steam expansively in engines employed to power machinery. The Cornish practice of expansive operation could not be easily transferred to mill operations, where the application of the steam engine to industrial processes generally required a smooth and regular piston movement.

Some of the problems created by the irregular power cycle could be solved by expanding the steam in two separate cylinders, reviving in this way, the Woolf double cylinder compound design, which had not been crowned with much success in Cornwall. This however involved some loss of fuel efficiency. We can safely assume that this technical solution was feasible because the Woolf compound expansive engine, as we have seen, had become the favourite technical choice in France in many industrial applications from the 1820s.

Von Tunzelmann has calculated the "threshold" coal price at which, for rotative applications around 1835, it would have been economically worthwhile to install a new high-pressure expansive engine, instead of a lowpressure one, as $12 \mathrm{~s}$. per ton. ${ }^{23}$ This result, according to Von Tunzelmann, goes some way in the direction of rehabilitating Lancashire entrepreneurs from the allegations of entrepreneurial failure to which contemporaries, such as Farey, had condemned them.

We can provide a new calculation of this threshold coal price in manufacturing applications in 1841 using a list of prices for the engines produced by Benjamin Hick. Hick was one of the pioneers of the introduction of compound high-pressure expansive engine on the Woolf plan in the textile industries and his engines are probably to be considered as best-practice for the time.

22 N. Von Tunzelmann, op. cit. (3), p. 73. In several cases steam engines in water-works were worked around the clock for long periods, thus the most plausible estimates are those on the high side. For example, the Cornish engine of East London Waterworks for the first eighteenth months worked 24 hours per day with only occasional stoppages, see Civil engineer and architect journal, February 1840, p. 66.

23 Von Tunzelmann, op. cit. (3), p. 91. 
The theory and practice of steam engineering in Britain and France, 1800-1850

\begin{tabular}{|c|c|c|c|c|}
\hline Table 1 & Cornish & Boulton \& Watt & Coal price (s. per ton) & Coal price (s per ton.) \\
\hline Duty (millions of foot-pounds) & 90.81 & 40.049 & & \\
\hline Coal Consumption (lbs per HP-hour) & 2.05 & 4.65 & & \\
\hline HP & 135 & 71.50 & & \\
\hline Total costs $(\mathrm{f})$ & 7600 & $(-)$ & & \\
\hline Capital costs per HP (f) & 56.30 & (45) & & \\
\hline Capital costs per HP per annum (f) & 5.63 & 4.50 & & \\
\hline \multicolumn{5}{|c|}{ Threshold coal price for replacing an already working engine (s. per ton) } \\
\hline (4500 hrs.) & & & 21.58 & \\
\hline (5000 hrs.) & & & 19.42 & \\
\hline (5500 hrs.) & & & 17.65 & \\
\hline (6000 hrs.) & & & 16.18 & \\
\hline (6500 hrs.) & & & 14.94 & \\
\hline \multicolumn{5}{|c|}{ Threshold coal price for a new engine (s. per ton) } \\
\hline (4500 hrs.) & & & & 4.33 \\
\hline (5000 hrs) & & & & 3.90 \\
\hline (5500 hrs.) & & & & 3.54 \\
\hline (6000 hrs.) & & & & 3.25 \\
\hline (6500 hrs) & & & & 3.00 \\
\hline
\end{tabular}

table 1: Profitability of a high pressure engine for pumping applications, 1839

Sources: Duty, total costs and HP delivered are from T. Wicksteed, An Experimental Inquiry, op. cit. Coal consumption per HP-hour is calculated as 186.12/duty (see Pole, Treatise on the Cornish Engine, London, 1844, p. 171); the hypothetical cost per HP of a Watt pumping engine is based on N. Von Tunzelmann, Steam power and British industrialization to 1860, op. cit., p. 54; interest + depreciation rate set at $10 \%$ (see discussion in John W. Kanefsky, The diffusion of power technology in british industry, 1760-1870, PhD thesis, University of Exeter, 1979, pp. 167-170).

table 2: Profitability of a compound high pressure engine for a textile mill, 1841

Sources: coal consumption and data on engine and boiler costs are from Hills, Power from Steam, Cambridge, Cambridge University Press, 1989, p. 119. In calculating capital costs p.a., following Von Tunzelmann, Steam power, p. 72, we have made these assumptions: depreciation rate set at $7.5 \%$ p.a. for the engine and at $12.5 \%$ p.a. for the boiler, interest rate set at $5 \%$. For calculating the threshold coal price, we have assumed 3800 working hours per year, see, Von Tunzelmann, Steam power, p. 73.

\begin{tabular}{|c|c|c|c|c|c|c|c|c|}
\hline \multirow{2}{*}{$\begin{array}{l}\text { Table } 2 \\
\begin{array}{l}\text { Coal consumption } \\
\text { (Ibs per HP hour) }\end{array}\end{array}$} & \multicolumn{3}{|c|}{$\begin{array}{c}\text { Low pressure } \\
\text { condensing engine }\end{array}$} & \multicolumn{3}{|c|}{ Woolf compound } & $\begin{array}{c}\text { Threshold coal } \\
\text { price for a } \\
\text { new engine } \\
\text { (s per ton) }\end{array}$ & $\begin{array}{l}\text { Threshold } \\
\text { coal price for } \\
\text { replacing an } \\
\text { existing engine } \\
\text { (s per ton) }\end{array}$ \\
\hline & \multicolumn{3}{|c|}{14} & \multicolumn{3}{|c|}{5} & & \\
\hline HP & $\begin{array}{c}\text { Engine } \\
(\mathrm{f})\end{array}$ & $\begin{array}{l}\text { Boiler } \\
\text { (f) }\end{array}$ & $\begin{array}{l}\text { Capital } \\
\text { costs per } \\
\text { HP p. a. } \\
\text { (f) }\end{array}$ & $\begin{array}{l}\text { Engine } \\
(\mathrm{f})\end{array}$ & $\begin{array}{l}\text { Boiler } \\
\text { (f) }\end{array}$ & $\begin{array}{l}\text { Capital } \\
\text { cost per } \\
\text { HP p.a. } \\
\text { (f) }\end{array}$ & & \\
\hline 6 & 330 & 50 & 8.33 & 335 & 65 & 8.88 & 0.71 & 11.63 \\
\hline 10 & 435 & 65 & 6.58 & 450 & 100 & 7.38 & 1.05 & 9.66 \\
\hline 12 & 480 & 80 & 6.17 & 510 & 120 & 7.06 & 1.17 & 9.25 \\
\hline 16 & 550 & 100 & 5.39 & 620 & 150 & 6.48 & 1.43 & 8.49 \\
\hline 20 & 630 & 120 & 4.99 & 720 & 180 & 6.08 & 1.42 & 7.96 \\
\hline 25 & 710 & 150 & 4.60 & 800 & 220 & 5.54 & 1.23 & 7.26 \\
\hline 30 & 770 & 180 & 4.26 & 870 & 260 & 5.14 & 1.16 & 6.74 \\
\hline 40 & 960 & 240 & 4.05 & 1130 & 320 & 4.93 & 1.15 & 6.46 \\
\hline 50 & 1170 & 280 & 3.91 & 1350 & 400 & 4.78 & 1.14 & 6.25 \\
\hline
\end{tabular}




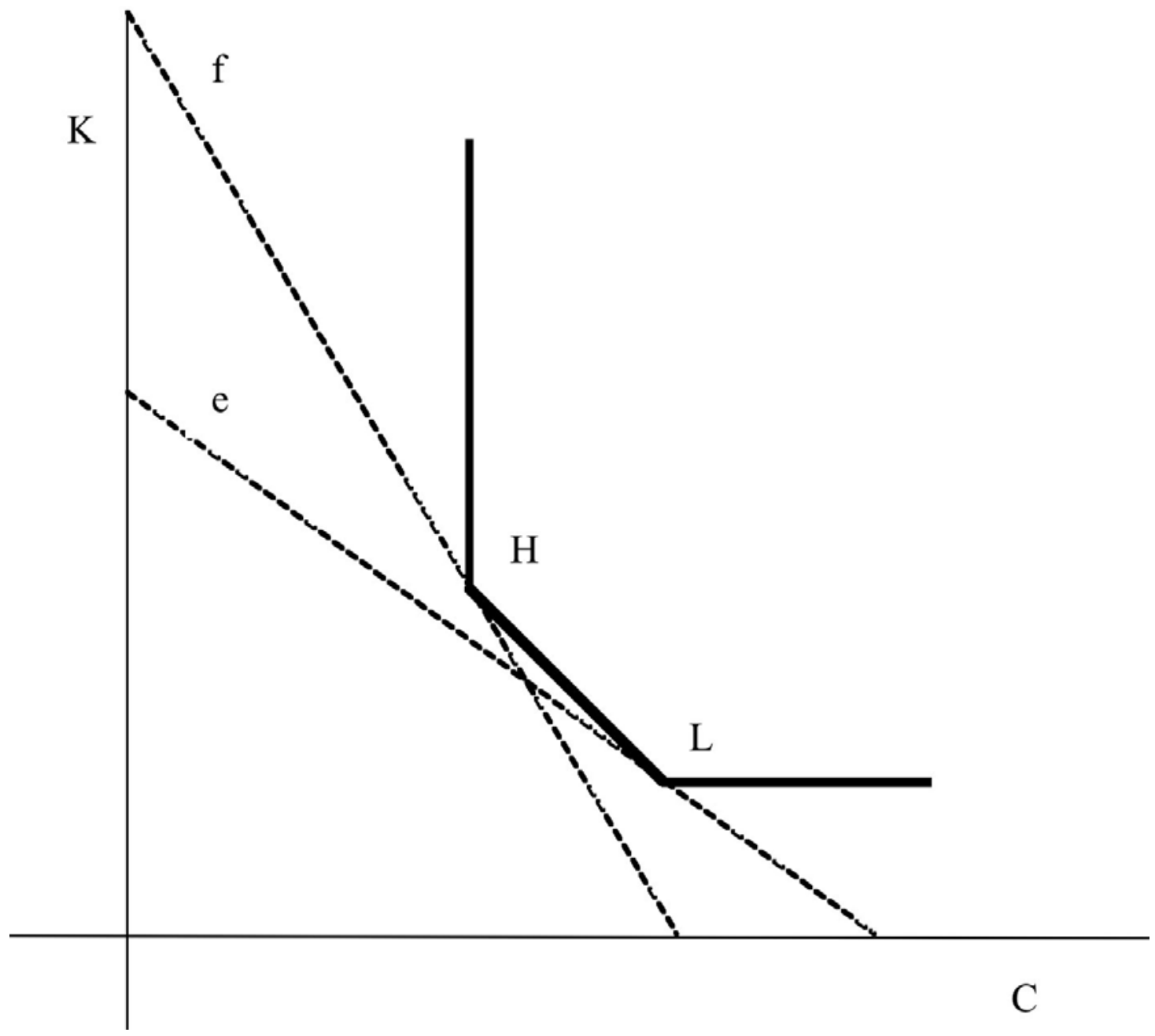

fig. 2 - Choice of technique in England and France in the 1810s

In Table 2 we report Hick's prices and estimates of coal consumption and our calculation of the threshold coal prices. When installing a new engine, for the most common sizes in this period (i.e., 40 and $50 \mathrm{HP}$ ), it would have been economically justified to adopt high-pressure expansive engines even in locations with a low coal price. The calculated threshold coal price for engines of 30, 40 and $50 \mathrm{HP}$ is equal to slightly more than $1 \mathrm{~s}$. a ton, which is even lower than the cost of "slack" coal at the colliery pithead. When a low-pressure engine was already installed, results are less clear-cut and possibly consistent with maintaining the low-pressure engine as favourite technical choice if coal prices were lower than $7 \mathrm{~s}$. Overall, our results indicate a greater cost effectiveness of the high-pressure expansive engine than the one originally estimated by Von Tunzelmann. ${ }^{24}$

24 Our calculation suggests that threshold price computed by von Tunzelmann for 1835 is overrated. The source of this overestimation is in the estimated increase in capital costs resulting from the adoption of the Cornish high pressure boiler, which von Tunzelmann assumes to increase in direct proportion with
What are the implications of these calculations if we take into account the French context? In the 1830s, the average price of coal in French manufacturing districts was probably around $36 \mathrm{~s}$. per ton and nowhere in France, the price of coal was less than $28 \mathrm{~s}$. per ton. ${ }^{25}$ Given these different circumstances of coal prices, and against the background of the profitability assessments

heating surface (this amounts to multiply the price of the "corresponding" low-pressure boiler by 7.5). Thus, for a $30 \mathrm{HP}$ engine, he puts total boiler cost at $f 1500$. Casual evidence shows that this errs far too much on the high side. In 1838, three boilers for a 60" engine for the Fresnillo Mine in Mexico were sold for $f 963$ (Barton, The Cornish Beam Engine, Truro, 1965, p. 280). In 1841, James Sims offered, in an advertisement published on the West Briton, a 80" pumping engine for $\mathrm{f} 2600$, inclusive of boilers (Barton, ibid., p. 52). These figures are broadly consistent with the prices of table 3 . In this respect, one has to take into account that in low coal price regions, steam engine manufacturers like Hick, generally avoided to construct the full-size Cornish boiler, opting for a "shortened" and cheaper version of the elongated Cornish cylindrical boiler. 25 See, Von Tunzelmann, op cit. (3), p. 277-278. 


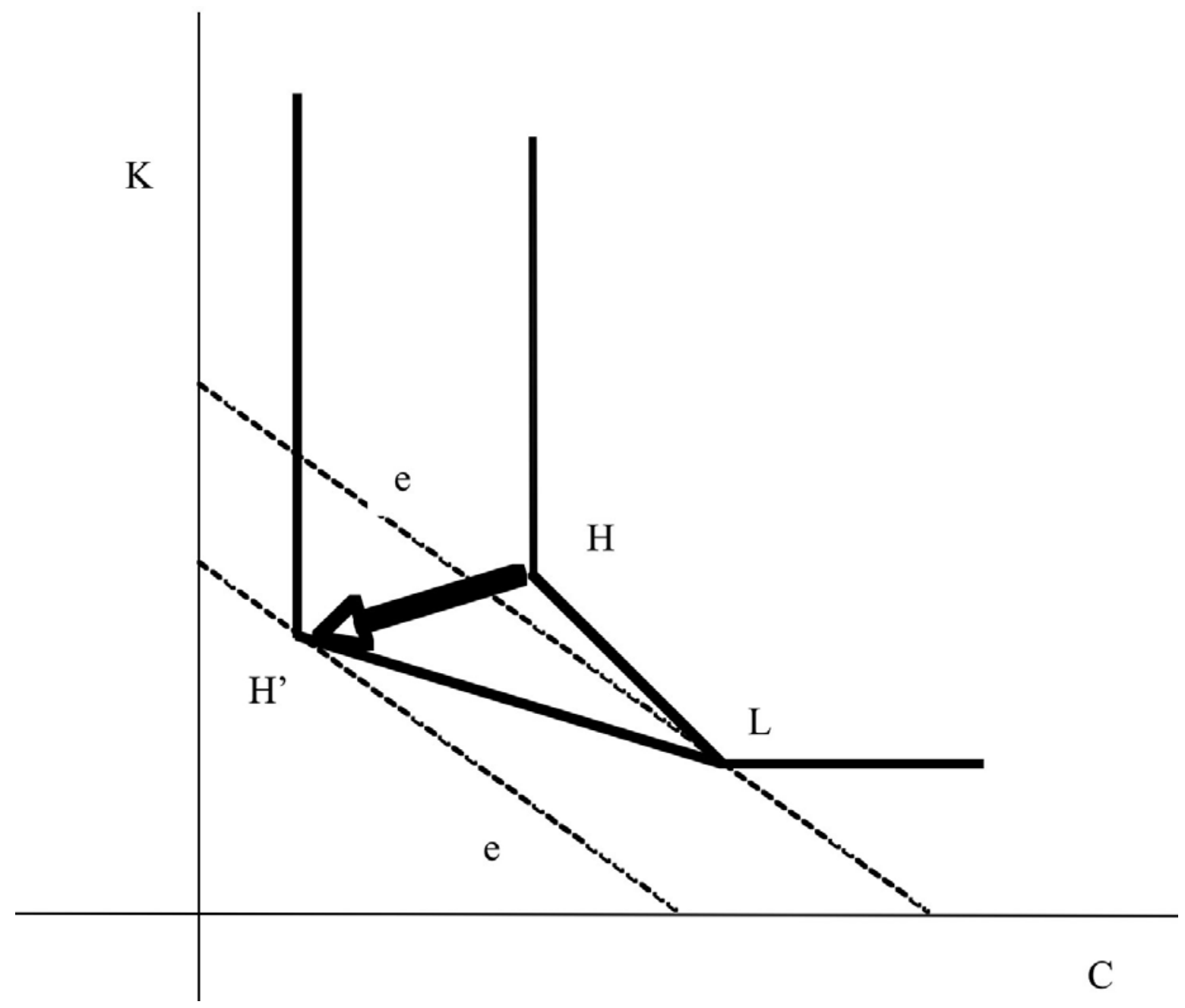

Fig. 3 - Choice of technique in England and France in the 1840s

carried out above, the quick shift to the high pressure expansive engine in French manufacturing does not come as a surprise.

Actually, our assessment shed a very favorable light on the actions of French engineers and entrepreneurs revealing a good alertness in importing and developing rather quickly a steam engine design that could fit into the French environment.

\section{Interpretation}

In our judgment, the model proposed by Paul David in his reassessment of the Rothbarth-Habakkuk debate provides an interpretive framework that can be fruitfully applied to the case of the different practices in England and in France in the first half of the nineteenth century. ${ }^{26}$ The essential feature of David's model, in comparison with the traditional neoclassical model of technical choice, is the idea that technical progress is, to a large extent, "localized" around specific techniques (that is to

26 Paul A. David, Technical choice, Innovation and economic growth, Cambridge, Cambridge University Press, 1975. say, improvements in one techniques do not "spill over" to other points of the unit isoquant). In case of localized technical change, different factor endowments can lead to persistent differential rates of technical progress between different environments (regions or countries).

Figure 2 illustrates the choice between a Watt low pressure engine and a Woolf high pressure expansive engine in the 1810s. The plan represents all the possible combinations of coal (lbs. per HP-hour) and capital (f per HP). Concerning the factor proportion of the two engines, the high pressure expansive engine involved higher capital outlays (in particular due to the higher cost of the high pressure boilers), but it has a clear advantage over the low pressure engine in terms of fuel efficiency. In figure 2, point $\mathrm{H}$ represents the high pressure expansive engine and point $L$ represents the low pressure engine. The availability of only two techniques constraints the possibilities of factor substitution in response to changes in factor prices. In figure 2, this is represented by the shape of the kinked isoquants passing through to the points $\mathrm{H}$ and $\mathrm{L}$. At least in principle, entrepreneurs could 
also decide to produce employing a linear combination of the two techniques. The dotted lines e and $f$ represent respectively the factor prices prevailing in England and in France. The slope of dotted the lines is equal to the ratio between the price of coal and the rental cost of capital. Given the much higher average price of coal prevailing in France, the slope of the $f$ line is higher than the slope of the e line. Note that when the ratio between factor prices is equal to the slope of the HL segment, an entrepreneur will be different between the two types of engines. If the ratio between factor prices is higher than the slope of $\mathrm{HL}$, the favorite option is the high pressure expansive engine, vice versa when the ratio of factor prices is lower than the slope of $\mathrm{HL}$, the favorite option is the low pressure expansive engine. Figure 2, may be taken to represent the period of the 1810s. In these conditions, it was rational for French entrepreneurs and engineers to adopt a high pressure expansive engine and for English entrepreneurs to stick with the Watt low pressure engine (with the exception of areas such as Cornwall where coal prices were relatively high).

Figure 3 represents instead the period of the late 1830 s and early 1840s. While the efficiency of the low pressure engine had remained stagnant (the main improvements to this design were geared to improve the reliability of the machine), progress in the fuel efficiency of the high pressure engine was very remarkable (as charted for example in the duty reports of the engines installed in Cornish mines). Also for France, the available shreds of evidence suggest a similar rapid improvement. This is represented by the movement from $\mathrm{H}$ to $\mathrm{H}^{\prime}$. Thus, as shown in figure 3 , we have a situation in which the adoption of high pressure expansive engine would be economically justified also in locations with relatively low coal prices (as shown in the two profitability assessments carried out in the previous section). In this new situation the reluctance to adopt the high pressure expansive engine is not anymore justified also in the coal abundant country.

To conclude, we can summarize our re-assessment, which is consistent with the arguments put recently forward by Allen for explaining the onset of industrialization in England and its successive diffusion in Europe, as follows. ${ }^{27}$ During the eighteenth century early steam power technology was an innovation that was actually suitable of substantial application only in the British context of low coal prices. However, in retrospect, the curiosity and the interest of the French scientific and engineering establishment in this technology, despite its limited cost effectiveness in the French circumstances, was not entirely frivolous. The early episodes of importing or designing steam engines in France and the speculative efforts of the French scientific establishment provided a fundamental basis that was probably an indispensable prerequisite for the later successful adaptation of the highpressure expansive engine in France. Thus, when in the early nineteenth century, the use of high-pressure opened the doors for a fuel-saving trajectory of improvement that was well suited with French circumstances, France was ready to seize the new opportunity.

27 Allen, op. cit. (14), the case of the steam engine is analyzed in chapter 7 . 